\title{
Langkah Promosi Objek Wisata Daerah Untuk Meningkatkan Pengetahuan Masyarakat Pada Dinas Pariwisata, Pemuda Dan Olah Raga Kabupaten Magelang
}

\author{
Prio Susilo ${ }^{1)}$, Atun Yulianto ${ }^{2)}$ \\ Akademi Pariwisata BSI Yogyakarta \\ E-mail: priosusilo1105@gmail.com ${ }^{1)}$, atun.aty@bsi.ac.id ${ }^{2)}$
}

\begin{abstract}
Magelang Regency has many regional attractions that can be explored by the community, ranging from nature, religion and artificial. Until now, the number of tourist visits to Magelang Regency has not been evenly distributed on all existing tourist objects. This condition is caused by several factors, including the unknown yet other tourist objects besides the Borobudur temple in Magelang Regency. Promotional steps for regional attractions by Dinas Pariwisata, Pemuda Dan Olah Raga Kabupaten Magelang (DISPARPORA) implemented through several media, both print and electronic. This promotion step is intended to provide knowledge to the general public about the many potentials in the form of regional tourism objects owned by Magelang Regency. The presentation of this study uses descriptive qualitative methods supported by surveys to provide a real picture of activities Dinas Pariwisata, Pemuda Dan Olah Raga in implementing the steps to promote tourism in the region. The results of this study indicate that there is a shift in the promotion steps that have been carried out by DISPARPORA Magelang Regency in promoting its tourist attraction. The shift in the way this promotion lies in the media is used with tendencies carried out through online media rather than conventional (offline) methods for the years now. The way to promote it is very appropriate to use to see the tendency of today's society to use gadget tools for surfing in the virtual world through social media and other online facilities. However, there are still obstacles in carrying out this tourism promotion effort, namely the limited human resources that can manage all kinds of social media accounts and the DISPARPORA website in Magelang Regency. HR (Human Resources) is more preoccupied with formal employment services. This makes the promotion of regional tourist attraction owned by Magelang Regency not yet optimally conveyed to the community. The steps to solve this problem are by organizing training related to information technology that is currently developing.
\end{abstract}

Keyword : Objects, Promotions, Tourism

Abstrak - Kabupaten Magelang memiliki banyak objek wisata daerah yang dapat eksplorasi masyarakat, mulai dari alam, religi maupun buatan. Hingga saat ini jumlah kunjungan wisatawan ke Kabupaten Magelang belum merata pada keseluruhan obyek wisata yang ada. Kondisi ini disebabkan oleh beberapa faktor, antara lain belum dikenalnya obyek-obyek wisata lain selain candi Borobudur di Kabupaten Magelang. Langkah promosi bjek wisata daerah oleh Dinas Pariwisata, Pemuda Dan Olah Raga Kabupaten Magelang (DISPARPORA) dilaksanakan melaui beberapa media, baik cetak maupun elektronik. Langkah promosi ini ditujukan untuk memberikan pengetahuan kepada masyarakat luas tentang banyaknya potensi yang berupa objek wisata daerah yang dimiliki Kabupaten Magelang. Penyajian penelitian ini menggunakan metode diskriptif kualitatif yang didukung survey untuk memberikan gambaran nyata atas kegiatan Dinas Pariwisata, Pemuda Dan Olah Raga dalam melaksanakan langkah-langkah promosi wisata daerahnya. Hasil penelitian ini menunjukkan bahwa terjadi pergeseran langkah promosi yang telah dilakukan oleh DISPARPORA Kabupaten Magelang dalam mempromosikan daya tarik wisatanya. Pergeseran cara promosi ini terletak pada media yang digunakan dengan kecenderungan dilakukan melalui media online dibanding cara konvensional (offline) untuk tahun-tahun sekarang ini. Cara berpromosi ini sangat tepat digunakan melihat kecenderungan masyarakat jaman sekarang yang lebih banyak menggunakan sarana gadget untuk berselancar didunia maya melalui media sosial dan fasilitas online lainnya. Namun demikian masih ada kendala dalam menjalankan upaya promosi wisata ini yaitu keterbatasan sumber daya manusia yang dapat mengelola dengan baik segala macam account media sosial maupun website DISPARORA Kabupaten Magelang. SDM lebih banyak disibukkan dengan pekerjaan formal kedinasan. Hal ini menjadikan langkah promosi daya tarik wisata daerah yang dimiliki Kabupaten Magelang belum optimal tersampaikan kepada masyarakat. Adapun langkah penyelesaiakan masalah ini adalah dengan penyelenggaraan pelatihan-pelatihan terkait tehnologi informasi yang berkembang saat ini.

Kata Kunci: Objek, Promosi, Wisata

\subsection{Latar Belakang}

Dalam UU RI No. 10 Tahun 2009 tentang Kepariwisataan disebutkan bahwa,
Wisata adalah kegiatan perjalanan yang dilakukan oleh seseorang atau sekelompok orang dengan mengunjungi tempat tertentu 
untuk tujuan rekreasi, pengembangan pribadi, atau mempelajari keunikan daya tarik wisata yang dikunjungi dalam jangka waktu sementara, sedangkan Pariwisata adalah berbagai macam kegiatan wisata dan didukung berbagai fasilitas serta layanan yang disediakan oleh masyarakat, pengusaha, Pemerintah, dan Pemerintah Daerah.

Disamping elemen kepariwisatan tersebut, dunia pariwisata juga tidak lepas dari keberadaan daerah tujuan wisata yang sering disebut destinasi wisata. Suatu daerah tujuan wisata dikatakan sebagai destinasi wisata apabila memiliki obyek yang menjadi daya tarik dan fasilitas wisata sebagai penunjangnya. Obyek dan daya tarik wisata merupakan unsur yang paling penting dalam menarik wisatawan untuk berkunjung memalui berbagai upaya promosinya. Jika banyak wisatawan yang berkunjung dampak yang diharapkan adalah adanya peningkatan pendapatan suatu daerah dari sektor kepariwisataan.

Banyak kota baik di luar maupun dalam negeri yang menggantungkan pendapatan daerahnya pada sektor pariwisata, salah satunya adalah Kabupaten Magelang. Kabupaten Magelang memiliki daya tarik panorama alam yang indah, karena di kelilingi oleh beberapa gunung antara lain Merapi, Merbabu, Sumbing, Sindoro serta pegunungan Menoreh. Terdapat satu objek daya tarik wisata yang menjadi andalan Kabupaten Magelang yaitu terdapat Candi Borobudur. Obyek wisata peninggalan sejarah di masa lampau ini, kini mendapat perlindungan dari UNESCO sebagai salah satu warisan dunia. Selain Candi Borobudur, masih banyak terdapat sejumlah Candi di antaranya Candi Mendut, Candi Pawon, Candi Ngawen, Candi Canggal (Candi Gunungwukir), Candi Selogriyo, Candi Gunung Sari, Candi Lumbung (Sengi), Candi Pendem dan Candi Asu (Larisa, 2018). Kabupaten Magelang juga mempunyai satu museum yang terletak di jalan antara Candi Mendut dan Borobudur, yaitu Museum Senirupa Haji Hidayat.

Obyek wisata alam Kabupaten Magelang memiliki beberapa obyek wisata, antara lain kawasan wisata Arung Jeram Citra Elo, Telaga Bleder, Kolam Renang KalibeningPayaman, Gardu Pandang Ketep Pass, Curug Silawe, Losari Coffe Plantion, Pemandian Air Panas Candi Umbul, Air Terjun Sekar Langit, di samping itu Sungai Progo dan Sungai Elo juga sering di gunakan untuk wisata Arung Jeram. Beberapa obyek wisata religi yang ada di Kabupaten Magelang antara lain "Langgar Agung" Pangeran Diponegoro, Makam Kyai Condrogeni, Makam Sunan Geseng, dan
Makam Raden Santri. Sementara itu, untuk seni budaya dan kriya terdapat beberapa Obyek wisata dan Daya Tarik Wisata (DTW) antara lain kesenian tradisional, kerajinan cenderamata, kerajinan mebel dan interior, serta makanan khas.

Dinas Pariwisata, Kepemudaan dan Olahraga (DISPARPORA) Kabupaten Magelang merupakan unsur pelaksana Pemerintah Daerah di bidang kebudayaan dan kepariwisataan. Tugas pokok dinas ini adalah menyelenggarakan urusan rumah tangga Pemerintah Daerah di bidang kepariwisataan. Bagian dari tugas DISPARPORA diantaranya berusaha meningkatkan promosi daya tarik wisata untuk meningkatkan jumlah kunjungan wisatawan, sehingga retribusi yang dihasilkan dapat menyumbang Pendapatan Asli Daerah (PAD) sesuai target yang dibebankan oleh pemerintah Kabupaten Magelang. Oleh Karena itu langkah nyata dijalin kepada semua pihak terkait untuk saling mendukung dalam berpromosi mengenalkan potensi wisata dan menarik wisatawan untuk berkunjung.

Permasalahan yang muncul, hingga saat ini jumlah kunjungan wisatawan ke Kabupaten Magelang belum merata pada keseluruhan obyek wisata yang ada. Hal tersebut dikarenakan belum maksimalnya langkah promosi dinas terkait, sehingga tidak dikenalnya sebagian obyek-obyek wisata yang ada di Kabupaten Magelang. Faktor lain yang menjadi persoalan adalah tanda penunjuk arah menuju obyek wisata yang masih perlu diperbanyak, keamanan dan fasilitas penunjang pariwisata yang perlu ditingkatkan dari sisi kuantitasnya. Sejalan dengan banyaknya potensi wisata di Kabupaten Magelang, maka Dinas Pariwisata Kepemudaan dan Olahraga Kabupaten Magelang melakukan langkah promosi wisata melalui media cetak dan media elektronik untuk menarik sebanyak mungkin calon pengunjung.

Sesuai hasil pengamatan peneliti, pengelolaan media elektronik terutama website dan media sosial yang ada di Dinas Pariwisata, Kepemudaan dan Olahraga Kabupaten Magelang perlu untuk ditingkatkan, sehingga dampaknya lebih maksimal pada jumlah kunjungan. Terlepas dari hal tersebut pengelolaan media elektronik membutuhkan SDM yang handal dalam menulis berita dan update informasi terkini secara kontinyu, sehingga tingkat kepercayaan dan antusiasme berkunjung masyarakat semakin meningkat dengan informasi yang diberikan. Berdasarkan uraian latar belakang, penelitian ini bertujuan untuk mengetahui langkah promosi DISPARPORA Magelang, faktor pendukung 
promosi dan kendala-kendala yang dihadapi dalam kegaitan promosi wisata DISPARPORA kabupaten Magelang.

\subsection{Kajian Teori \\ 2.1.1. Pengertian Objek Wisata Dan Pariwisata \\ Pengertian objek (daya tarik) wisata} adalah suatu tempat yang memiliki nilai lebih dari tempat pada umumnya, memiliki kelebihan, keunggulan, dan keistimewaan menjadi daya tarik bagi setiap orang yang melihat atau merasakannya (Tribun Wisata, 2016). Contohnya, Candi Borobudur di Kabupaten Magelang, Jawa Tengah, memiliki daya tarik bagi wisatawan, karena keindahan ukiran, kemegahan bangunan, dan keelokannya sebagai cagar budaya Indonesia.

Menurut UU RI No 9 Tahun 1990 tentang Kepariwisataan, dinyatakan bahwa obyek dan daya tarik wisata adalah segala sesuatu yang menjadi sasaran wisata baik itu terbentuk secara alami, pembangunan obyek dan daya tarik wisata yang dilakukan dengan cara mengusahakannya, mengelolanya dan membuat obyek-obyek baru sebagai obyek dan daya tarik wisata yang siap menarik kunjungan wisatawan (Basahona, 2016).

Pariwisata berasal dari bahasa sansekerta, "pari" yang berarti sering kali atau banyak melakukan dan kata "wisata" yang berarti perjalanan. Jadi istilah pariwisata adalah perjalanan berulang-ulang atau banyak melakukan perjalanan dari satu tempat ke tempat lainnya yang diakhiri ditempat keberangkat semula (Suryadana, 2013 :46).

Wisata adalah kegiatan perjalanan yang dilakukan oleh seseorang atau sekelompok orang dengan mengunjungi tempat tertentu untuk tujuan rekreasi, pengembangan pribadi, atau mempelajari keunikan daya tarik wisata yang dikunjungi dalam jangka waktu sementara, sedangkan Pariwisata adalah berbagai macam kegiatan wisata dan didukung berbagai fasilitas serta layanan yang disediakan oleh masyarakat, pengusaha, Pemerintah, dan Pemerintah Daerah (UU RI No. 10 Tahun 2009 tentang Kepariwisataan)

Menurut Marpaung dalam Hanief dan Pramana (2018:1-2), Pariwisata adalah "suatu perjalanan yang dilakukan orang untuk sementara waktu, yang diselenggarakan dari suatu tempat ke tempat lain meninggalkan tempat semula, dengan suatu perencanaan dan dengan maksud bukan untuk berusaha atau mencari dfkah ditempat yang dikunjungi, tetapi semata-mata untuk menikmati kegiatan pertamasyaan dan rekreasi atau untuk memenuhi keinginan yang beraneka ragam".
Dari beberapa pendapat tentang pariwisata dapat dijelaskan, bahwa pariwisata merupakan suatu kegiatan dimana seseorang atau kelompok orang melakukan perjalanan dari tempat asal ke tempat lain dengan tujuan rekreasi menikmati suasana alam, budaya, kebiasaan dari tempat lain untuk mendapatkan pengalaman baru dan bukan untuk tinggal menetap ataupun mencari nafkah dengan diakhiri kembali ditempat semula.

\subsubsection{Pengertian Dan Tujuan Promosi}

Promosi merupakan salah satu kegiatan komunikasi pemasaran yang penting bagi perusahaan dalam upaya mempertahankan kelangsungan usaha, melalui upaya promosi penjualan untuk memasarkan barang atau jasa dari suatu perusahaan kepada konsumen. Pengertian Promosi Menurut Gitosudarmo (2008:285) adalah "Kegiatan yang ditujukan untuk mempengaruhi konsumen agar dapat mengenal produk yang ditawarkan perusahaan, sehingga konsumen merasa tertarik untuk membeli produk tersebut". Jadi promosi dapat berupa interkasi penjual dan pembeli melalui kegiatan komunikasi yang dilakukan untuk penyampaian pesan tentang kondisi suatu produk. Kegiatan promosi harus direncanakan terlebih dahulu agar berjalan dengan baik secara kondusif sampai calon konsumen menjadi tahu dan diakhiri dengan ketertarikan untuk membeli produk yang dipromosikan tersebut.

Setiap promosi yang lakukan perusahaan, tentu memiliki berbagai tujuan salah satunya menarik konsumen. Tujuan utama dari kegiatan promosi menurut Swastha dan Irawan (2008:353), yaitu :

1. Modifikasi tingkah laku orang-orang. Melakukan komunikasi selalu mempunyai beberapa alasan, misalnya mencari kesenangan, mencari bantuan, memberikan pertolongan atau instruksi, memberikan informasi, mengemukakan ide dan pendapat. Promosi dari segi lain, berusaha merubah tingkah laku, pendapat dan memperkuat tingkah laku yang ada.

2. Memberitahu. Kegiatan promosi dilakukan untuk memberitahu pasar yang dituju tentang penawaran perusahaan. Sebelum mereka mengetahui produk dan apa faedahnya, maka mereka tidak akan membeli barang atau jasa tersebut. Promosi yang bersifat memberitahu ini juga penting bagi konsumen karena dapat membantu dalam pengambilan keputusan untuk membeli.

3. Membujuk. Promosi yang bersifat membujuk ini diarahkan untuk mendorong 
pembelian. Sifat membujuk ini akan menjadi dominan jika produk yang bersangkutan mulai memasuki tahap pertumbuhan didalam siklus kehidupan.

4. Mengingatkan. Tujuan promosi yang bersifat mengingatkan dilakukan untuk mempertahankan merek produk di hati masyarakat dan perusahaan berusaha untuk mempertahankan pembeli yang ada.

Dapat kita simpulkan bahwa tujuan langkah promosi adalah kegiatan untuk memberitahu atau menginformasikan, membujuk dan mengingatkan pembeli agar dimungkinkan terjadinya keputusan membeli. Oleh karena itu, promosi yang dilakukan oleh lembaga atau perusahaan dapat diarahkan untuk mempengaruhi tingkat pengetahuan dan sikap pembeli agar bersedia membeli. Perusahaan juga dapat mengadakan promosi lanjutan untuk meningkatkan pengalaman pembeli, sehingga dapat membantu dalam mengkonfirmasikan keputusannya.

\subsubsection{Media Promosi (Promotion Mix)}

Berbagai kegiatan dan model yang memiliki berbagai unsur penunjang yang dapat dikombinasikan untuk mengkomunikasikan produk dengan konsumen melalui suatu media yang biasa disebut media promosi (promotional mix). Menurut Lupiyoadi (2006: 120) memberikan definisi sebagai berikut: "Perangkat promosi mencangkup aktivitas periklanan, personal selling, promosi penjualan, public relation, informasi dari mulut ke mulut (word of mouth), direct marketing dan publikasi".

1. Periklanan

Merupakan salah satu bentuk dari komunikasi impersonal yang digunakan oleh perusahaan barang atau jasa. Peranan periklanan dalam pemasaran jasa adalah untuk membangun kesadaran terhadap keberadaan jasa yang ditawarkan, menambah pengetahuan konsumen tentang jasa yang ditawarkan, membujuk konsumen untuk membeli atau menggunakan jasa tersebut dan membedakan diri perusahaan satu dengan perusahaan lain yang mendukung positioning jasa.

2. Penjualan Perorangan (Personal Selling) Penjualan perseorangan mempunyai peranan penting dalam pemasaran jasa, karena interaksi secara personal antara penyedia jasa dan konsumen sangat penting, jasa disediakan oleh orang bukan mesin dan orang merupakan bagian dari produk jasa.

3. Promosi Penjualan
Promosi penjualan adalah semua kegiatan yang dimaksudkan untuk meningkatkan arus barang atau jasa dari produsen sampai pada penjualan akhirnya.

4. Hubungan Masyarakat (Public Relation) Merupakan kiat pemasaran lainnya, dimana perusahaan tidak hanya harus berhubungan dengan pelanggan, pemasok dan penyalur, tetapi juga harus berhubungan dengan kumpulan kepentingan publik yang lebih besar.

5. Informasi dari Mulut ke Mulut (Word of Mouth)

Dalam hal ini peranan orang sangat penting dalam mempromosikan jasa. Pelanggan akan berbicara kepada pelanggan lain yang berpotensial tentang pengalamannya dalam menerima jasa tersebut, sehingga informasi dari mulut ke mulut ini sangat besar pengaruhnya terhadap pemasaran jasa dibandingkan dengan aktivitas komunikasi lainnya.

6. Pemasaran Langsung (Direct Marketing) merupakan unsur terakhir dalam bauran komunikasi dan promosi.

Pendapat tersebut dapat disimpulkan bahwa bauran promosi merupakan kegiatan yang terdiri dari periklanan, personal selling, promosi penjualan yang semuanya direncanakan untuk mencapai tujuan program penjualan.

\subsubsection{Langkah Komunikasi Pemasaran Dalam Promosi \\ Dasar pengembangan kegiatan} promosi adalah cara komunikasi. Komunikasi terjadi dengan proses pemindahan pengertian dalam bentuk gagasan atau informasi dari seseorang ke orang lain.

Menurut Gitosudarmo (2008: 295) komunikasi efektif meliputi langkah-langkah, antara lain:

1. Mengidentifikasi Target Audiens

Komunikasi ini dapat efektif apabila sasarannya jelas. Dalam hal ini sasarannya adalah pembeli potensial, pemakai, penentu keputusan serta pihakpihak yang dapat memberi pengaruh dalam proses keputusan pembelian.

2. Menentukan Respon yang Diinginkan

Respon yang diinginkan bagi setiap pemasar adalah pembelian saat itu juga, namun juga tidak memungkinkan dapat terjadi pembelian untuk masa yang akan datang.

3. Perancangan Pesan

Setelah tanggapan yang diinginkan sudah diketahui atau sudah didapatkan, perusahaan perlu menyusun pesan yang tepat. Pesan ini harus menarik dan 
mampu membangkitkan minat serta keinginan kuat untuk membeli.

Jadi semakin baik komunikasi pemasaran yang tercipta, maka akan meningkatkan kepuasan yang semakin tinggi bagi semua pihak yang terlibat didalamnya. Dalam hal ini kegiatan promosi selalu berkaitan dengan kegiatan komunikasi yang efektif.

\subsection{Metode Penelitian}

Metode penelitian yang digunakan dalam artikel ini adalah metode diskriptif kualitatif. Menurut Sugiyono (2005:21) metode diskriptif adalah metode yang digunakan untuk menggambarkan atau menganalisis penelitian, tapi tidak digunakan untuk mengambil suatu kesimpulan yang lebih luas. Metode diskriptif kualitatif ini menekankan pada suatu aspek pemahaman yang lebih mendalam terhadap suatu masalah daripada melihat permasalahan. Menurut Moelong (2005:5) metode kualitatif adalah penelitaan yang menerapakan metode wawancara secara terbuka untuk mengetahui atau memahami sikap, pandangan dan perlakuan individu maupun sekelompok orang. Untuk mendapatkan data dalam penelitian ini, diperlukan beberapa cara yang berkesinambungan supaya dapat mencapai tujuan dari laporan yang diharapkan yaitu melalui wawancara, studi pustaka, observasi, dan dokumentasi.

\subsection{Hasil Dan Pembahasan}

\subsubsection{Sejarah dan Perkembangan Instansi}

Kantor Dinas Pariwisata Kepemudaan

dan Olah raga Kabupaten Magelang merupakan instansi teknis pelaksana pembangunan daerah dan penyelenggaraan pemerintah di bidang Kepariwisataan Kepemudaan dan Keolahragaan. Dinas Pariwisata Kabupaten Magelang berdiri sejak tanggal 23 Februari 1984 berdasarkan PP No. 21 Tahun 1982 tentang pemindahan ibukota Kabupaten daerah Tingkat II Magelang dari wilayah Kotamadya daerah tingkat II Magelang ke Kota Mungkid sebagai ibukota Magelang (lembaran Negara Tahun 1982 Nomor 36).

\subsubsection{Visi dan Misi Disparpora Kabupaten Magelang}

Visi Disparpora Kabupaten magelang adalah : Terwujudnya Kabupaten Magelang Sebagai Kabupaten Wisata yang Berdaya Saing dan berwawasan Budaya serta Terwujudnya Masyarakat Yang Mandiri, Inovatif, Sehat dan Berprestasi. Visi tersebut mengandung makna bahwa Dinas Pariwisata Kepemudaan dan Olah Raga Kabupaten Magelang secara bersama-sama dan bersinergi diarahkan untuk mencapai kondisi yang diinginkan pada akhir perencanaan. Sedangkan Misi Disparpora Kabupaten Magelang adalah :

1. Menjadikan Kabupaten Magelang sebagai Kabupaten tujuan wisata kualitas unggulan.

2. Mengembangkan kualitas Obyek Wisata sehingga laku jual dengan mutu pengelolaan semakin profesional.

3. Menjalin kerjasama dengan pihak lain dengan prinsip saling menguntungkan.

4. Menciptakan sistem pemerintahan yang baik dan demokratis.

5. Meningkatkan kepeloporan, peran serta dan prestasi yang mendukung pengembangan kreatifitas, ketrampilan dan kewirausahaan pemuda.

6. Meningkatkan pembinaan, pemasyarakatan, serta penyediaan sarana dan prasarana olahraga.

\subsubsection{Tugas Dan Fungsi Organisasi}

Tugas dan fungsi Dinas Pariwisata Kepemudaan dan Olahraga berdasarkan Peraturan Daerah Kabupaten Magelang Nomor 19 Tahun 2016, tentang Organisasi dan Tata Kerja Dinas Daerah Kabupaten Magelang, selanjutnya dalam rangka pelaksanaannya ditindaklanjuti dengan Peraturan Bupati Nomor: 16 Tahun 2016 tentang Penjabaran Tugas Pokok, Fungsi dan Tata Kerja Dinas Pariwisata Kepemudaan dan Olahraga Kabupaten Magelang berkedudukan sebagai unsur pelaksana otonomi daerah yang dipimpin oleh seorang Kepala Dinas berada dibawah dan bertanggung jawab kepada Bupati melalui Sekretaris Daerah.

Untuk melaksanakan tugas tersebut, Dinas Pariwisata Kepemudaan dan Olahraga mempunyai bagian tugas dan fungsi sebagai berikut:

1. Kepala Dinas Pariwisata Kepemudaan dan Olahraga

Memimpin pelaksanaan tugas Dinas Pariwisata, Kepemudaan dan Olahraga dalam menyelenggarakan urusan pemerintahan di bidang pariwisata, kepemudaan dan olahraga yang menjadi kewenangan daerah Sekretaris Dinas Pariwisata Kepemudaan dan Olahraga.

2. Sekretaris Dinas Pariwisata Kepemudaan dan Olahraga

Memimpin pelaksanaan tugas Sekretariat Dinas Pariwisata, Kepemudaan dan Olahraga yang meliputi perumusan konsep kebijakan, pelaksanaan, pengkoordinasian, pemantauan, evaluasi, dan pelaporan bidang perencanaan, keuangan, kepegawaian, ketatausahaan, pengelolaan 
barang milik daerah, kerumahtanggaan, kelembagaan, ketatalaksanaan, kehumasan, dokumentasi, kerjasama, hukum, perpustakaan, kearsipan.

3. Kepala Sub Bagian Program Memimpin pelaksanaan tugas Subbagian Program yang meliputi penyiapan bahan perumusan kebijakan, pengkoordinasian, pelaksanaan, pengadministrasian, pemantauan, evaluasi, dan pelaporan bidang perencanaan, pemantauan, pengendalian, evaluasi, pelaporan.

4. Kepala Sub Bagian Keuangan

Memimpin pelaksanaan tugas Subbagian Keuangan yang meliputi penyiapan bahan perumusan kebijakan, pengkoordinasian, pelaksanaan, pengadministrasian, pemantauan, evaluasi, dan pelaporan bidang penatausahaan keuangan .

5. Kepala Sub Bagian Umum dan Kepegawaiaan

Memimpin pelaksanaan tugas Subbagian Umum dan Kepegawaian yang meliputi penyiapan bahan perumusan kebijakan, pengkoordinasian,

pengadministrasian, pelaksanaan, evaluasi, dan pelaporan bidang kepegawaian, ketatausahaan, pengelolaan barang milik daerah, kerumahtanggaan, kelembagaan, ketatalaksanaan, kehumasan, dokumentasi, kerjasama, hukum, perpustakaan.

6. Kepala Bidang Destinasi dan Industri Pariwisata

Memimpin pelaksanaan tugas Bidang Destinasi dan Industri Pariwisata yang meliputi penyiapan bahan perumusan kebijakan, pelaksanaan, pengkoordinasian, pengadministrasian, pemantauan, evaluasi, dan pelaporan bidang destinasi dan industri pariwisata.

7. Kepala Seksi Destinasi Pariwisata Memimpin pelaksanaan tugas Seksi Destinasi Pariwisata yang meliputi penyiapan bahan perumusan kebijakan, pengkoordinasian, pelaksanaan, pengadministrasian, pemantauan, evaluasi, dan pelaporan bidang destinasi pariwisata.

8. Kepala Seksi Industri Pariwisata

Memimpin pelaksanaan tugas Seksi Industri Pariwisata yang meliputi penyiapan bahan perumusan kebijakan, pengkoordinasian, pengadministrasian, pelaksanaan, pariwisata.

9. Kepala Bidang Pemasaran dan Kelembagaan Pariwisata
Memimpin pelaksanaan tugas Bidang Pemasaran dan Kelembagaan Pariwisata yang meliputi penyiapan bahan perumusan kebijakan, pengkoordinasian, pelaksanaan, pengadministrasian, pemantauan, evaluasi, dan pelaporan bidang pemasaran dan kelembagaan pariwisata.

10. Kepala Seksi Pemasaran Pariwisata

Memimpin pelaksanaan tugas Seksi Pemasaran Pariwisata yang meliputi penyiapan bahan perumusan kebijakan, pengkoordinasian, pelaksanaan, pengadministrasian, pemantauan, evaluasi, dan pelaporan bidang pemasaran pariwisata.

11. Kepala Seksi Kelembagaan Pariwisata Memimpin pelaksanaan tugas Seksi Kelembagaan Pariwisata yang meliputi penyiapan bahan perumusan kebijakan, pengkoordinasian, pelaksanaan, pengadministrasian, pemantauan, evaluasi, dan pelaporan bidang kelembagaan pariwisata.

12. Kepala Bidang Kepemudaan Memimpin pelaksanaan tugas Bidang Kepemudaan yang meliputi perumusan kebijakan, pengkoordinasian, pelaksanaan, pengadministrasian, pemantauan, evaluasi, dan pelaporan bidang kepemudaan.

13. Kepala Seksi Pemberdayaan dan Pengembangan Pemuda

Memimpin pelaksanaan tugas Seksi Pemberdayaan dan Pengembangan Pemuda yang meliputi penyiapan bahan perumusan kebijakan, pengkoordinasian, pelaksanaan, pengadministrasian, pemantauan, evaluasi, dan pelaporan bidang pemberdayaan dan pengembangan pemuda.

14. Kepala Seksi Perlindungan Pemuda dan Pemberdayaan Lembaga Kepemudaan Memimpin pelaksanaan tugas Seksi Perlindungan Pemuda dan Pemberdayaan Lembaga Kepemudaan yang meliputi penyiapan bahan perumusan kebijakan, pengkoordinasian, pelaksanaan, pengadministrasian, pemantauan, evaluasi, dan pelaporan bidang perlindungan pemuda dan pemberdayaan lembaga kepemudaan.

15. Kepala Bidang Keolaharagaan Memimpin pelaksanaan tugas Bidang Keolahragaan yang meliputi perumusan kebijakan, pelaksanaan, pengadministrasian, pemantauan, evaluasi, dan pelaporan bidang keolahrgaan. 
16. Kepala Seksi Pemberdayaan dan Pengembangan Olahraga

Memimpin pelaksanaan tugas Seksi Pemberdayaan dan Pengembangan Olahraga yang meliputi penyiapan bahan perumusan kebijakan, pengkoordinasian, pelaksanaan, pengadministrasian, pemantauan, evaluasi, dan pelaporan bidang Pemberdayaan dan Pengembangan Olahraga.

17. Kepala Seksi Pengembangan ilmu Pengetahuan dan Teknologi Industri Olahraga

Memimpin pelaksanaan tugas Seksi Pengembangan IImu Pengetahuan dan Teknologi Industri dan Lembaga Keolahragaan yang meliputi penyiapan bahan perumusan kebijakan, pengkoordinasian, pelaksanaan, pengadministrasian, pemantauan, evaluasi, dan pelaporan bidang pengembangan ilmu pengetahuan dan teknologi industri dan lembaga keolahragaan.

\subsection{Pembahasan Penelitian}

\subsubsection{Langkah Promosi Wisata DISPARPORA Kabupaten Magelang} Kabupaten Magelang memiliki berbagai obyek dan daya tarik wisata yang menarik untuk dikunjungi. Wisata di Kabupaten Magelang yang sangat beragam adalah salah satu alasan mengapa Kabupaten Magelang ini menarik untuk dikunjungi. Keanekaragaman wisatanya antara lain wisata sejarah, wisata alam, wisata buatan, wisata budaya, wisata religi, dan wisata minat khusus. Pemerintah Daerah (Pemda) melalui Dinas Pariwisata Kepemudaan dan Olahraga Kabupaten Magelang melakukan berbagai langkah promosi wisata. Langkah promosi wisata tersebut yaitu:

1. Promosi Melalui Media Cetak

Media promosi yang digunakan DISPARPORA Kabupaten Magelang dengan media cetak yang berisi pesanpesan visual menggunakan kertas ataupun sejenisnya, diantaranya adalah :

a. Brosur:

Brosur memiliki nilai atau manfaat yang besar dalam periklanan karena bentuknya yang simpel dan mudah dibawa kemana-mana. Brosur dapat merincikan destinasi wisata dan alat komunikasi untuk membangun kesadaran adanya destinasi disuatu daerah. Tujuan utamanya adalah mengkomunikasikan potensi wisata secara tertulis kepada masyarakat sehingga terjadi penjualan wisata terutama di Kabupaten Magelang.

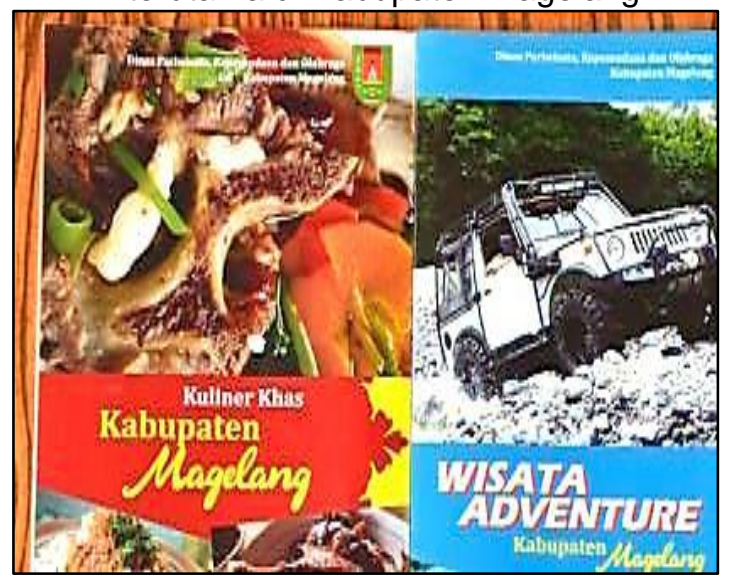

Sumber : Bagian Promosi DISPARPORA (2017)

Gambar 1. Brosur Wisata Kabupaten Magelang

b. Booklet

Banyaknya tempat wisata yang dapat dikunjungi di Kabupaten Magelang seringkali membuat para wisatawan menjadi kebingungan. Meskipun berbagai macam informasi dapat dengan mudah didapatkan melalui smartphone. Namun membuat panduan bagi wisatawan dapat dijadikan sebagai pilihan yang menarik. Booklet merupakan salah satu informasi tercetak sebagai upaya promosi DISPARPORA yang memiliki bentuk, ukuran, dan jumlah halaman yang ringkas sehingga mudah di bawa kemana-mana. Membuat informasi destinasi wisata dengan booklet membantu wisatawan melakukan pilihan kunjungan.

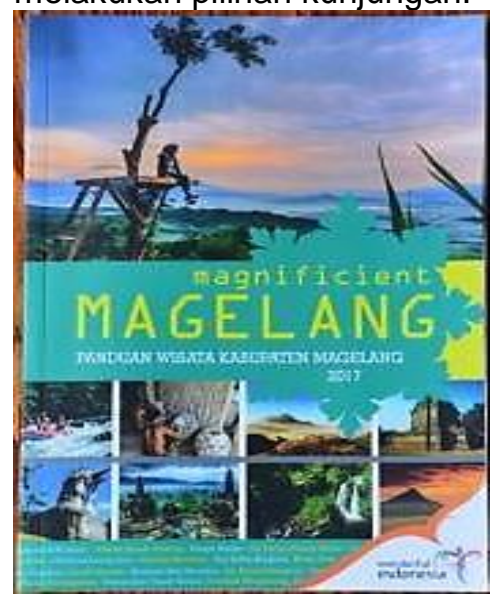

Sumber :Bagian Promosi Disparpora (2017)

Gambar 2. Booklet Wisata

2. Promosi Melalui Media Elektronik

Selain media cetak, pemanfaatan promosi DISPARPORA juga telah dilakukan 
dengan media internet. Hal ini dilatarbelakangi oleh meningkatnya pengguna internet disaat ini. Perkembangan teknologi telah merubah segalanya termasuk dalam bidang pariwisata. Berikut beberapa promosi DISPARPORA melalui media elektronik di antaranya:

\section{a. Website}

Cara yang paling efektif diera digital untuk memperkenalkan pariwisata di Kabupaten Magelang kepada masyarakat luas diantaranya adalah melalui website. DISPARPORA kabupaten Magelang dapat memperkenalkan objek wisata daerah dalam bentuk gambar, suara, dan video dalam websitenya untuk tujuan promosi pariwisata.

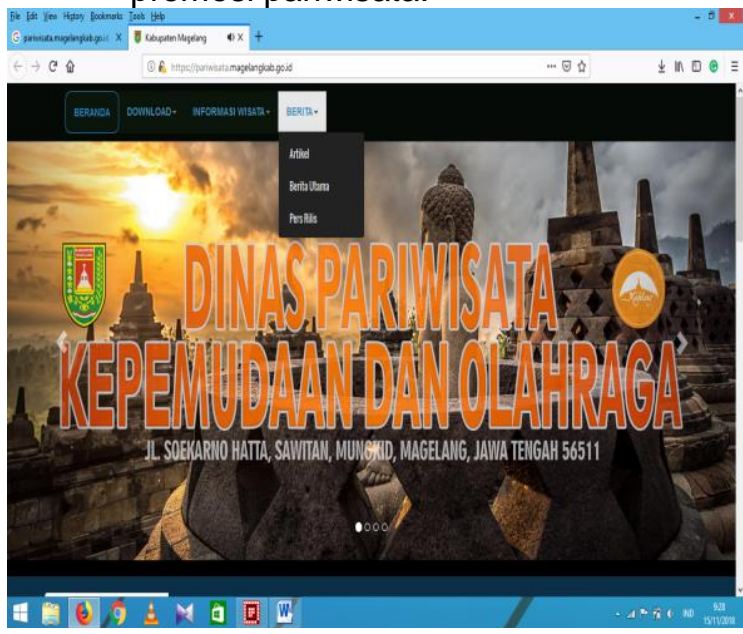

Sumber : pariwisata.magelangkab.go.id (2017) Gambar 3. Website Disparpora

Keuntungan dari website ini adalah luasnya informasi yang tersebar dimasyarakat. Namun kekurangannya adalah pada tingkat kepercayaan dan tidak semua masyarakat sudah terhubung internet sampai pelosok daerah.

b. Aplikasi Android

Panduan Wisata berbasis android telah dikembangkan DISPARPORA dalam bentuk aplikasi yang dapat didownload wisatawan, sehingga mudahkan pencarian detail informasi tentang daerah-daerah wisata yang ada di Kabupaten Magelang. Dalam pembangunan perangkat lunak ini, DISPARPORA bekerjasama dengan pihak-pihak terkait khususnya pengembang software untuk menyelesaiakan aplikasi ini, mulai dari perancangan, pembuatan, pengujian, perbaikan dan penyelesaian aplikasi.

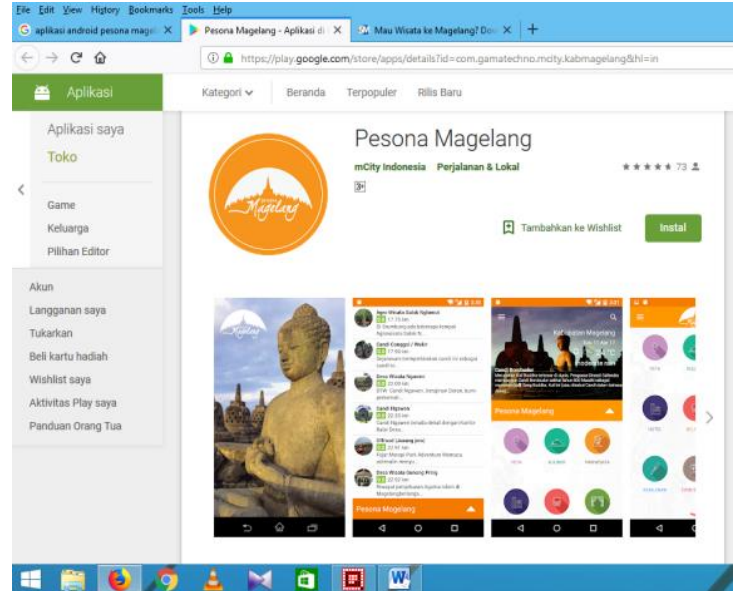

Sumber : Aplikasi Android Pesona Magelang (2017)

\section{Gambar 4. Aplikasi Android}

Perangkat lunak berbasis Android yang berisi Panduan Wisata Kabupaten Magelang ini dapat dijadikan sebagai alat pemandu wisatawan sekaligus media promosi objek wisata daerah di Kabupaten Magelang.

c. Sosial Media

Media sosial atau situs jejaring sosial seperti Facebook, Twitter, dan lainnya menjadi salah satu target DISPARPORA dalam menyelenggarkan promosi wisata online bagi Kabupaten Magelang. Hasilnya cukup efektif dalam menjaring wisatawan baru. Ada beberapa media sosial yang dimanfaatkan DISPARPORA dalam upaya promosi diantaranya facebook, whatapps, twitter dan instagram.

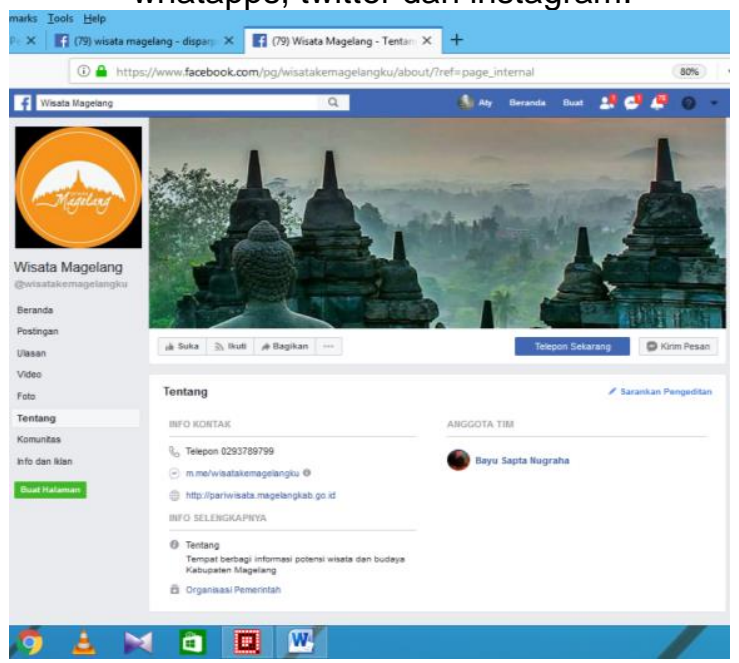

Sumber: Wisata magelang (2017)

Gambar 5. Facebook Wisata Magelang 


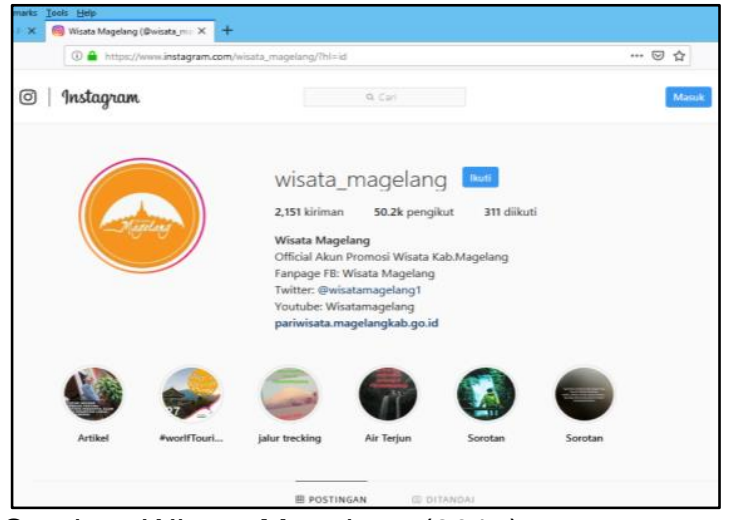

Sumber: Wisata Magelang (2017)

Gambar 6. Instagram Wisata Magelang

\subsubsection{Faktor Pendukung Promosi Disparpora Kabupaten Magelang \\ Dalam mengembangkan strategi} promosi daya tarik wisata di Kabupaten Magelang, Dinas Pariwisata Kepemudaan dan Olahraga Kabupaten Magelang mempunyai berbagai kegiatan pendukung dalam melakukan promosi diantaranya keaktifan DISPARPORA dalam mengikuti berbagai pameran wisata seperti Gebyar Wisata Budaya Nusantara di Jakarta setiap tahunnya yang di selenggarakan ditiap bulan Mei.

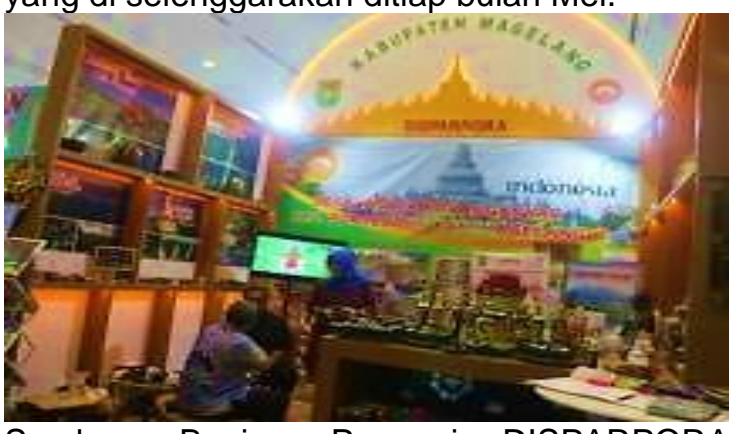

Sumber: Bagian Promosi DISPARPORA (2017)

Gambar 7. Pameran Wisata Budaya

Dalam event tersebut upaya yang dilakukan berupa kegiatan membagikan CD tetang wisata daerah Magelang, brosure dan leaflet. Disamping pameran DISPARPORA juga berperan serta dalam kegiatan rodshow promosi wisata ke daerah lain.

\subsubsection{Hambatan Dan Solusi DISPARPORA Kabupaten Magelang Dalam Melakukan Promosi Wisata \\ Dalam mempromosikan daya tarik} wisata di Kabupaten Magelang, DISPARPORA memiliki hambatan dalam segi teknis maupun SDM. SDM yang dimiliki tidak semuanya memahami dan mengerti penggunaan teknologi informasi yang sedang berkembang saat ini. Disisi lain pemanfaatan media cetak tentunya lebih membutuhkan anggaran yang tidak sedikit untuk mencetak selebaran dan booklet yang akan dibagikan.
Seiring dengan kemajuan media dan teknologi, aktivitas promosi mulai bergeser dari konvensional ke digital, diantaranya melalui internet. Upaya DISPARPORA untuk dapat memanfaatkan kemajuan tehnologi ini adalah dengan mengadakan training dan studi lanjut bagi SDM terpilih agar dapat menguasai keterampilan dalam menggunakan tehnologi digital saat ini. Dalam mengembangkan dan memasarkan promosi wisata di Kabupaten Magelang, DISPARPORA Magelang telah menjalin kerja sama promosi pariwisata dengan 13 Kabupaten/Kota yang tergabung dalam java promo 2017. Dimana tujuan kegiatan ini adalah untuk perluasan informasi promosi dan memajukan potensi pariwisata yang ada di Kabupaten/Kota masing-masing dengan membentuk forum komunikasi pelaku wisata daerah. Salah satu kegiatannya adalah dengan pembinaan desa wisata yang tujuannya untuk memperkenalkan potensi desa yang dimiliki tiap daerah kepada masyarakat luas.

\subsection{Penutup}

\subsubsection{Kesimpulan}

Kesimpulan berdasarkan hasil

penelitian yang telah dilakukan dan dari hasil pembahasan, Langkah promosi wisata pada Dinas Pariwisata, Kepemudaan dan Olahraga Kabupaten Magelang yaitu:

1. Langkah promosi wisata olen Disparpora Kabupaten Magelang telah dilaksanakan melaui dua media yaitu offline dan online. Media offline yang digunakan yaitu media cetak seperti brosur (leaflet), dan booklet. Sedangkan media online berjalan melalui media elektronik seperti website, aplikasi android, dan media sosial.

2. Faktor pendukung promosi wisata DISPARPORA Kabupaten Magelang adalah keaktifan berpartisipasi dalam berbagai event pameran dan promosi destinasi. Gebyar Wisata Budaya Nusantara di Jakarta setiap tahun pada bulan Mei adalah salah satu event rutin yang diikuti. Dalam tiap event pameran upaya membagikan CD wisata Magelang, brosure dan boklet serta aktif dalam roadshow promosi wisata ke daerah lain merupakan faktor penting dalam mendukung langkah promosi wisata kabupaten Magelang

3. Dengan pengadaan kegiatan training ataupun studi lanjut bagi SDM yang berkesinambungan dapat mengurangi kendala kurang kompetennya SDM memanfaatkan tehnologi informasi yang terus berkembang saat ini. Bekerjasama dengan dinas lain untuk promosi bersama 
dapat dimanfaatkan untuk mengurangi biaya-biaya promosi konvensional karena ditanggung bersama.

\subsubsection{Rekomendasi}

Berdasarkan pembahasan dan kesimpulan yang telah diuraikan, peneliti memberikan rekomendasi untuk mengurangi permasalahan yang ada, yaitu:

1. Meningkatkan jumlah SDM dalam pelatihan untuk menangani masalah promosi wisata digital.

2. Mengupayakan kerjasama dengan televisi dan radio lokal maupun nasional untuk penyebaran informasi wisata secara lebih luas.

3. Kerjasama dengan Dinas Kabupaten lain yang menangani masalah promosi wisata.

\section{Daftar Pustaka}

[1] Basahona, Ato. 2016. Pengertian obyek. https://www.atobasahona.com/2016/07/pe ngertian-objek-wisata.html. 5 Februari 2017

[2] Basu, Swastha dan Irawan. 2008. Manajemen Pemasaran Modern.Yogyakarta: Liberty.

[3] Gitosudarmo, Indriyo. 2008. Manajemen Pemasaran. Yogyakarta. BPFE Yogyakarta.
[4] Hanief, Shofwan Dan Pramana, Dian. 2018. Pengembangan Bisnis Pariwisata dengan Media Sistem Informasi. Yogyakarta : Penerbit ANDI

[5] Larisa, Vany. 2018. 15 Candi di Magelang Jawa Tengah Beserta Penjelasannya. http://sejarahlengkap.com/bangunan/cand i-di-magelang. 5 Agustus 2018

[6] Lupiyoadi, Rambat. 2006. Manajemen Pemasaran Jasa. Jakarta: Penerbit Salemba.

[7] Moelong, L.J. 2005. Metodologi Penelitian Kualitatif. Bandung: Remaja Rosda Karya.

[8] Sugiyono. 2005. Memahami Penelitian Kualitatif. Bandung: Alfabeta.

[9] Suryadana, M. Liga. 2013. Buku Sosiologi Pariwisata : Kajian Kepariwisataan Dalam Paradigma Integratif-Transformatif Menuju Wisata Spiritual. Bandung : Humaniora

[10] Tribun Wisata. 2016. Pengertian Wisata, Kepariwisataan, Wisatawan, dan Objek Wisata.

http://www.tribunwisata.com/2016/09/pen gertian-wisata-kepariwisataan-wisatawandan-objek-wisata.html . 5 Feruari 2017

[11] UU RI Nomor 9 Tahun 1990. Tentang Kepariwisataan.

[12] UU RI Nomor 10 Tahun 2009. Tentang Kepariwisataan. 